\title{
Perspectives on University Students' Self- Regulated Learning, Task-Avoidance, Time Management and Achievement in a Flipped Classroom Context
}

\author{
Lauri Hyppönen ${ }^{1}$ \\ University of Eastern Finland \\ Joensuu, Finland \\ Laura Hirsto2, 1 \\ University of Helsinki/University of Eastern Finland \\ Helsinki, Finland/Joensuu, Finland \\ https://orcid.org/0000-0002-8963-3036 \\ Erkko Sointu \\ University of Eastern Finland \\ Joensuu, Finland \\ https:// orcid.org/0000-0003-4001-7264
}

\begin{abstract}
Previous studies have shown that self-regulation plays a major role in learning in academic contexts. The ability to regulate one's behaviors guides us towards goals that we are trying to achieve. The theoretical background includes perspectives to self-regulation. The aim of the study was to investigate university students' self-regulation in relation to their academic achievement in a Flipped Classroom learning context. A total of 230 university students of a multidisciplinary research university participated in this study. The students were asked to complete an on-line questionnaire. The questionnaire included various items on self-regulation of learning, time-management, lack of regulation, and task-avoidance. The various perspectives related to students' self-regulation of learning seemed to form reliable dimensions and a functional structure in accordance with the composite variable from earlier studies. The students were divided into three statistically significant profile groups: Students with high self-regulation skills, Students with low self-regulation skills and Students with low selfregulation skills and high task-avoidance. The results showed that the
\end{abstract}

\footnotetext{
${ }^{1}$ This paper has two first authors with equal contribution.

${ }^{2}$ Corresponding author: Laura Hirsto, laura.hirsto@helsinki.fi, laura.hirsto@uef.fi
} 
students' self-regulation profile was related to academic achievement in Flipped Classroom courses. Especially students with low self-regulation skills and high task-avoidance were struggling. Self-regulation plays a major role in academic achievement and the choices that students make at universities.

Keywords: Self-regulation; task avoidance; time management; flipped classroom; learning environment

\section{Introduction}

In recent years, a pedagogical approach called Flipped Classroom (FC) has spread out to universities and has become popular. FC is defined as a studentcentered learning approach in which learning content is delivered outside of class, preferably online, and classroom hours are used for students to engage in collaborative learning activities (Bergmann \& Sams, 2015; Hao, 2016; Winter, 2018). In fact, FC is based on the socio-constructive learning perception, in which social interaction is seen as crucial for students' learning. The FC approach is usually conceived so that in the first phase of the learning process, students study the learning material on the internet during a certain time period. After that, in the following days, these issues are talked about, discussed, and applied further in a face-to-face session, to construct the knowledge about and knowhow on the subject area. The FC approach is not a very well theorized construct, and it does not guarantee a learner-centered learning culture as it focuses on moving tasks in space and time (e.g. Abeysekera \& Dawson, 2015). However, according to Mazur, Brown, and Jacobsen (2015), the Flipped Classroom approach that emphasizes collaborative learning, group work and accessibility can enable and support inquiry-based learning. According to Hao (2016), self-regulatory skills are crucial to achieving academic success in an FC context because of students' need to preview learning material beforehand. There is also evidence that the FC approach may allow more students' self-regulation than normal learning environments (Talbert, 2017). This may be because students are able to choose more freely when they study, schedule their own studying and, for example, choose how many times they go through the study material.

Earlier research has suggested that FC is seen positively in higher education, where, according to Hao (2016), the majority of the students felt that the learning experience was good and it met students' learning needs. However, some of the students did not prefer FC because they were unwilling to study the required learning material by themselves beforehand (Hao, 2016). In this study, we focus on how students' self-regulatory skills are present in the Flipped Classroom context and how this is related to learning achievement.

A lot of research has been done in the past decades on students' learning patterns in colleges and universities (cf. Gijbels, Donche, Richardson, \& Vermunt, 2014). Several studies have shown that the learning behavior may differ due to the students' age or the diversity of the students' approaches to learning and varying learning environments (Berliner \& Biddle, 1997; Parpala, Lindblom-Ylänne, Komulainen, Litmanen, \& Hirsto, 2010). In this respect, we all are individuals with varying backgrounds, and we bring our perceptions, skills 
and experiences to learning situations. Various psychological processes play key roles in how we try to achieve our goals. In this study, we focus on what kind of capabilities university students have in terms of regulating their own learning processes and how they are related to their learning achievements in a learning environment which utilizes the FC approach. The theoretical background in terms of self-regulation in this study is generally based on Zimmermann's (2005) self-regulated learning (SRL) theory, in which students' regulation of learning is considered to flow through three phases: forethought, performance and selfreflection phase. Self-regulated learning skills are considered to be important 21st century skills which support lifelong learning. The development of pedagogical approaches and, more generally, learning environments requires teachers to change their habits and practices of teaching, but more importantly, it also requires students to change their ways of learning. This study focuses on that. As we aimed at changing teaching-learning environments with the Flipped Classroom or Flipped Learning approach towards supporting more studentcentered or learner-centered learning, we also reduced teacher regulation of the teaching-learning situations. As teacher regulation decreases, it gives the students a possibility to increase the regulation of their own learning at the same time (e.g. Toivola, 2016; Toivola \& Silfverberg, 2015). Therefore, it is essential to investigate students' self-regulated learning skills in relation to achievement on courses that follow the Flipped Classroom approach.

Nowadays, educational technology plays a major role in learning environments, where studying in universities without a computer is tough or even impossible. Thus, information and communication technology (ICT) skills are crucial while studying in universities and using ICT environments. Previous studies have suggested that learning environments have an impact on how students are capable of learning (Entwistle, 2003; Parpala et al., 2010; Baeten, Kyndt, Struyven, \& Dochy, 2010). In the 21st century there is a need for innovative and constructive learning environments which facilitate students' active role and where students can regulate their own learning effectively (Schunk \& Ertmer, 2005) Vermunt \& Vermetten, 2004).

\section{Self-regulated learning as an important skill for higher education students}

Students who enter higher education studies have usually many years of experience of what it is to be a student. However, their capabilities of guiding and monitoring their own studying and learning processes vary. Students use different kinds of strategies in their learning processes; functional strategies are more likely to be used in future (Schunk \& Ertmer, 2005; Carver \& Scheier, 2005). According to Vermunt and Vermetten (2004), experienced students have more abilities to alternate between different learning strategies. Students that can vary their learning strategies by self-regulating their learning processes are more likely to succeed in academic tasks (e.g. Schunk, 1994; Boekarts \& Niemivirta, 2000; Heikkilä \& Lonka, 2006). Learning environments may also have an impact on students' self-regulated learning. Students prefer learning environments where they can regulate their own learning through the provided options (Schunk \& Ertmer, 2005). Previous studies have shown that students' undirected 
learning pattern seems to be negatively related to study achievements, while meaning-directed learning was associated with positive study achievements (Vermunt \& Vermetten, 2004). Regulation activities that are demonstrated before, during or after learning process steer the cognitive and affective activities and therefore lead, according to Vermunt and Vermetten (2004), indirectly to learning outcomes.

There are various theories about self-regulation. However, Zimmerman's (2005) theory of self-regulated learning (SRL) is widely used and well known, and according to Panadero (2017), it seems to form a basis for many cyclical process models of self-regulation. According to the SRL model, students are active learners who can regulate their own learning by many different ways and change those ways during the learning process (Schunk, 1994). SRL models are based on the constructive assumption, in which learners are seen as active and constructive participants in learning situations, building their own meanings, goals and strategies in the learning process (Pintrich, 2005).

According to Zimmerman (2005), self-regulated learning (SRL) includes the cognitive, metacognitive, motivational and emotional aspects of learning. Thus, it cannot be seen only as focusing on academic learning in formal contexts. It also has an important role in lifelong learning and, as such, as part of students' 21st century skills (e.g. Voogt, Erstad, Dede, \& Mishra, 2013). Self-regulation does not occur only while executing the task (performance phase), but also before (forethought phase) and after (self-reflection phase) it when planning incoming tasks and generating self-reflections that have an effect in later performances (Zimmerman, 2005). Several studies have found that students' personal, social, familiar, instructional, and environmental factors are related to students' self-regulation (Berliner \& Biddle, 1997; Baeten et al., 2010).

While Zimmermann (2005) suggested that we should perceive learning from various viewpoints, such as cognitive, metacognitive and emotional, Vermunt's (1996) study operationalizes learning in terms of three similar categories of strategies: cognitive, affective and metacognitive. A student uses cognitive activities while processing the learning content. Affective learning activities involve feeling competence in the learning process, and metacognitive regulation is used to regulate cognitive and affective learning activities, leading to results in learning (Vermunt, 1996).

How a student uses learning content outside of the syllabus can be seen as an academic self-regulatory skill (Vermunt \& Vermetten, 2004): high-achiever students are seen more as learning for understanding the subject matter (Entwistle \& Tait, 1990). Self-regulation of learning content also measures how much effort the student is willing to put on an academic task while performing it. Low self-regulatory skills are often consequences of personal problems, which according to Zimmerman (2005) may appear as apathy, disinterest or mood disorder. In formal learning contexts, lack of regulation has been related to ambivalent learning orientation and cooperation, which lead to an undirected learning style (Vermunt \& Verloop, 2000; Vermunt \& Vermetten, 2004) in which 
the student needs to rely on the teacher and other students instead of selfregulating their learning independently (Entwistle \& Peterson, 2004). Low emotional feelings about studies and a need of support can indicate lack of regulation. Vermunt and Vermetten (2004) define lack of regulation as follows: a student is unable to regulate their own learning process and perform upcoming tasks independently. Previous studies have shown that an undirected learning style has been related to low study success (Busato, Prins, Elshout, \& Hamaker, 1998).

A student's lack of regulation should be observed in time, or it might lead to task-avoidance because the student's regulatory skills are not at an appropriate level (Nurmi, Aunola, Salmela-Aro, \& Lindroos, 2003). Lack of regulation has been negatively related with optimism and positively with task-avoidance in previous studies, so lack of regulation can be seen as a negative phenomenon of learning (Heikkilä, Lonka, Nieminen, \& Niemivirta, 2012). If students are not able to develop their self-regulation skills from the state of lack of regulation, it may cumulate to a cycle of negativity and present further challenges for students' self-regulatory skills. Lack of regulation and low self-esteem have been seen as related to an undirected learning pattern, in which student try to rely on other students and teachers without having any motivation for learning (Entwistle \& Peterson, 2004).

As lack of regulation of learning and task avoidance may be related, task avoidance can be a problem for university students for many reasons. Moreover, for a teacher in higher education, it is hard to observe task avoidance in student behavior because students are often themselves responsible for keeping up with tasks and completing courses. Emotions are students' affective activities, which can make an academic task easier or make it more difficult (Vermunt \& Vermetten, 2004). Previous studies have shown that students with active selfregulation are more likely to succeed when facing challenges than students with a low self-esteem and regulation (Pintrich \& De Groot, 1990; Schunk \& Ertmer, 2005; Nurmi et al., 2003; Heikkilä, Niemivirta, Nieminen, \& Lonka, 2011). Some students also have dysfunctional orientation and therefore avoid upcoming tasks (Lonka et al., 2008). In general, low self-regulation has been related to taskavoidance and low academic achievement (Eronen, Nurmi, \& Salmela-Aro, 1998; Nurmi et al., 2003; Lonka et al., 2008). Low self-regulation is problematic in many ways: negativity towards school or formal education can lead to joining deviant peer groups (Zimmerman, 2005) where improving it can be even more difficult. Lack of regulation and high task avoidance may lead to negative cycles, as according to Nurmi et al. (2003), students who reported a high level of taskavoidance also referred to a lack of effort after failure.

University students use their time differently: some students make accurate timetables about their studies while others do not even own a calendar. Time management can be seen as a part of self-regulated learning processes as resource management (cf. Schunk, 2005), where students with active regulation of their learning are more capable of organizing, planning and managing time than students with low skills of self-regulation of learning (Schunk \& 
Zimmermann, 1997). Pintrich (2005) found that self-learners' and high-achievers' time use was beneficial because of high self-regulation. In an academic context, students with good time management skills use their time functionally and plan their activities beforehand. In terms of SRL, time management processes function mostly before the self-regulation process and during it. Karagiannopoulou and Milienos (2015) found that time management activities seem to be beneficial for learning as students with a strategic approach to learning tried to use time as well as possible and got the best learning achievements. Thus, time management may have important contributions to the regulation of learning as well as student achievement.

Skills for self-regulated learning affect study achievements because students are more likely to put the effort on activities that they value (Schunk \& Ertmer, 2005). There is evidence that well-organized students accomplished better in learning achievements (Baeten et al., 2010).

\section{The purpose of the study}

This study aims to reveal what kind of self-regulated learning skills university students report and how their skills are related to learning achievement during Flipped Classroom courses. For this end, we first needed to construct a contextually meaningful instrument which is sensitive to the dimensions of the FC approach. Therefore, we needed to include perspectives from various instruments used to measure self-regulated learning.

This research seeks to address the following questions:

1) How do the theoretically collected measures seem to describe dimensions of self-regulated learning?

a. Structural validity and internal consistency of the used measures?

b. How are university students' self-regulation of learning, taskavoidance and time management capabilities connected on a personoriented level?

2) How are students' self-regulation profiles related to the learning outcome level in a Flipped Classroom context?

\section{Methods}

The convenience sample included 230 university students $\left(M_{\text {age }}=25.75 ; \mathrm{SD}_{\text {age }}=\right.$ 7.07) from a large Finnish interdisciplinary research university and its 16 courses. More particularly, there were 162 female students (70\%) and 68 male students $(30 \%)$, and the gender distribution of the data represents Finnish university students well. The respondents of this study were from various disciplinary backgrounds such as health sciences, social sciences, humanistic disciplines, educational sciences, information sciences and forestry. Data were collected during academic year 2016-2017 by an electronic survey at the end of flipped classroom courses. The teachers of these courses had participated in FC training and had received knowledge about FC (e.g. core content analysis of the curriculum, pre-materials with technology, in-class activities, assessment practices and students' guidance and counselling) and how to implement FC in their teaching. This set the foundation for teaching, learning and learning 
environments. However, the actual FC environments, particularly in the contact meetings, were based on the training and varied based on different disciplinary and teacher needs. Thus, no general FC learning environment could be identified. Response rate varied from $25 \%$ to $75 \%$ in the courses. Courses with a response rate lower than $25 \%$ were not used in the analysis as the data contained either extremely negative or positive responses violating normal distribution assumptions of the data. Thus, we considered data from courses with a response rate lower than $25 \%$ as biased data. Participation in the study was voluntary for students, and informed consent was obtained from each individual respondent. The study follows the EU General Data Protection Regulation (GDPR).

The research questionnaire used in this study was composed from several functional questionnaires: the Inventory of learning styles (ILS; Vermunt, 1994), the Strategy attribution questionnaire (SAQ; Nurmi, Salmela-Aro, \& Haavisto, 1995) and the Motivated strategies for learning questionnaire (MSLQ; Pintrich, 1991). According to Valli (2018), the best way to collect information is to use questionnaires which have been tested previously and proved functional. We used only parts (i.e. scales) of the above-mentioned instruments fitting to the research questions. The selection of instrument scales for investigating selfregulation skills was done in the beginning of the research project. To our best knowledge, this kind of joint combination of scales questionnaire has not been used to measure self-regulation before.

The ILS pattern contains cognitive, self-regulative, metacognitive and motivational components about students' learning (Vermunt \& Vermetten, 2004). In this study, we used a part of it to measure the students' self-regulated learning in terms of process and outcome (SRP, six questions; e.g. "To test my own progress, I try to describe the content of a paragraph in my own words"), contents (SRC, four questions; e.g. "If I do not understand a study text well, I try to find other literature about the subject concerned"), and lack of regulation (LR, five questions; e.g. "I realize that it is not clear to me what I have to remember and what I do not have to remember"). Students responded to the ILS with a five-point Likert type scale: $1=$ rarely to $5=$ always. Back-translation procedures were used by the research team Ameba (Hirsto, Sointu and Valtonen) in order to have a functional translation of the ILS into Finnish.

The SAQ consists of 10 different subscales which measure students' thinking and operation strategies while learning in higher education (Nurmi et al., 1995). We used task-avoidance (TA) with four questions (e.g. "If I assume I will face trouble, I usually find something else to do"), and students answered the questionnaire with a six-point Likert-type scale $(1=$ totally disagree $-6=$ totally agree). With the SAQ, an already existing Finnish translation was used (e.g. Hirsto, 2012).

The Motivated strategies for learning questionnaire (MSLQ) consists of two different sections, which are the motivation section and the learning strategies section (Pintrich, 1991). We used the learning strategies section, where four questions related to time management (TIM; e.g. "I make good use of my study 
time for this course") were used and students responded to them with a sixpoint Likert-type scale ( $1=$ totally disagree $-6=$ totally agree). With this composition of measures, we were able to achieve a more comprehensive view of students' self-regulation skills. In this study we report the above-mentioned measures (not all the project data is reported). With the MSLQ, we used an already existing Finnish translation. In this study the learning achievement was measured by the grade which the students achieved at the end of the course varying from 1 to 5 .

First, we tested the structural validity of our SAQ and MSLQ items with exploratory factor analysis (EFA) with principal axis factoring (PAF) and direct oblimin rotation. According to Field (2018), principal axis factoring is preferred if the aim of the study is to restrict conclusion to the collected sample. Oblique rotation is used when factors can correlate with each other (Field, 2018). The Kaiser-Meyer-Olkin (KMO) measure for sampling adequacy, Bartlett's test, eigenvalues, scree plot and the amount of variance explained, and rotated factor loading were used to evaluate the adequacy and fit of the data. We expected the $\mathrm{KMO}$ to reach a value of 0.8 to indicate reliable factors, Bartlett's test $p<0.05$ to indicate that the correlations between variables are significant, and eigenvalues as well as the scree plot to present the best solution for the structure. EFA can be done for measures with different scales (i.e. 1-5 and 1-6) because EFA is based on correlations, and thus, the scores are already standardized.

The structural validity results were confirmed from the perspective of internal consistency of subscales (i.e. factors). For this form of reliability, Cronbach alpha (a) was used. We expected alpha level 0.7 (e.g. Nunnally, 1978) or higher to indicate adequate internal consistency of factors.

The results of EFA and (a) were used to calculate composite scores (i.e. mean sum variables) in order to hold the original metric of the measures for interpretation purposes. Then, to acquire a person-oriented exploratory approach, we conducted a k-means cluster analysis with all of the composite scores (i.e. SRP, SRC, LR, TA, TIM) to find potentially different kinds of student groups in terms of their capabilities to regulate their own learning. In k-means cluster analysis the respondents are divided into groups as homogenous as possible, but between groups there are as big differences as possible (MacQueen, 1967; Han \& Kamber, 2001; Heikkilä, 2010). Cluster analysis forms groups that are not known beforehand, and the researcher's task is to name them (Metsämuuronen, 2011) based on the results, earlier theories and empirical evidence. Then, the result of the clusters was compared to the learning achievement. In the Finnish university context, grades are $1=$ sufficient, $2=$ satisfactory, $3=$ good, $4=$ very good and $5=$ excellent. Grades were divided into three different groups, grades 1 and 2 making up the low learning achievement group, grades 3 and 4 the intermediate learning achievement group and grade 5 the high learning achievement group. To compare the clusters to learning achievements, a One-way ANOVA test was carried out to find differences between groups. After that we performed Tukey's post hoc test to identify where the differences were. According to Metsämuuronen (2011), Tukey's post 
hoc test is a conservative test which does not indicate differences between two clusters too easily. Finally, Cohen's d was calculated estimating the effect size of detected significances, where $\mathrm{d}<0.1$ does not indicate effects, $\mathrm{d}=0.2-0.4$ indicates small effects and $\mathrm{d}=0.5-0.7$ indicates intermediate effects (Cohen, 1988). SPSS statistics v25 was used for analyzing the data.

\section{Results}

\section{Various dimensions of self-regulated learning}

The result of the EFA demonstrates adequate functioning of the selected measures, and the factor loadings are high on their own factor with few exceptions. A KMO value of 0.85 verified the sampling adequacy for the analysis. The Bartlett test was below 0.01, indicating significant differences from zero correlations. Initially, the EFA produced a six-factor solution with eigenvalue larger than 1 . However, only one item loaded to the sixth factor and we wanted to follow the original measurement structure. Thus, we tested a fivefactor structure and it replicated the original structure. The alphas ranged from 0.69 to 0.89 , indicating adequate internal consistency of the suggested factor structure. The EFA result was confirmed with the Cronbach alpha (a), and all the factors met the set criteria. Table 1 presents the means, standard deviation, factor loading after rotation, $a$, eigenvalues and percentage of variance (explained variance). 
Table 1: Exploratory Factor Analysis (Principal Axis Factoring) with oblique rotation

\begin{tabular}{|c|c|c|c|c|c|}
\hline \multirow[b]{2}{*}{ Item } & \multicolumn{5}{|c|}{ Rotated Factor Structure } \\
\hline & Factor 1 & Factor 2 & Factor 3 & Factor 4 & Factor5 \\
\hline$\overline{\text { TA1 }}$ & -.87 & & & & \\
\hline TA2 & -.74 & & & & \\
\hline TA3 & -.71 & & & & \\
\hline TA4 & -.89 & & & & \\
\hline LR1 & & .54 & & & \\
\hline LR2 & & .70 & & & \\
\hline LR3 & & .60 & & & \\
\hline LR4 & & .46 & & & \\
\hline LR5 & & .53 & & & \\
\hline SRP1 & & & .64 & & \\
\hline SRP2 & & & .47 & & \\
\hline SRP3 & & & .47 & & \\
\hline SRP4 & & & .82 & & \\
\hline SRP5 & & & .74 & & \\
\hline SRP6 & & & .46 & & \\
\hline SRC1 & & & & .67 & \\
\hline SRC2 & & & & .59 & \\
\hline SRC3 & & & & .65 & \\
\hline SRC4 & & & & .55 & \\
\hline TIM1 & & & & & .55 \\
\hline TIM2 & & & & & .53 \\
\hline TIM3 & & & & & .61 \\
\hline TIM4 & & & & & .65 \\
\hline Eigenvalues & 5.84 & 3.41 & 1.52 & 1.34 & 1.06 \\
\hline$\%$ of variance & 25.37 & 14.80 & 6.60 & 5.82 & 4.62 \\
\hline Cronbach $a$ & .88 & .71 & .79 & .70 & .69 \\
\hline Original sum variable mean & 3.17 & 2.32 & 2.81 & 2.94 & 3.86 \\
\hline Original sum variable SD & 1.13 & 0.70 & 0.75 & 0.74 & 0.95 \\
\hline
\end{tabular}

The exploratory factor analysis shows that each group presented an underlying factor based on the theoretical background with five factors (eigenvalue $>1$ ). The Cronbach a varied between .69 to .88 , meeting the criteria set for the study. The means varied from TA $(\mathrm{M}=3.17, \mathrm{SD}=1.13$; range 1-6) and TIM $(\mathrm{M}=3.86$, $\mathrm{SD}=0.95$; range 1-6) to $\mathrm{LR}(\mathrm{M}=2.32, \mathrm{SD}=0.70$; range $1-5), \mathrm{SRP}(\mathrm{M}=2.81, \mathrm{SD}=$ 0.75 ; range 1-5), and SRC $(\mathrm{M}=2.94, \mathrm{SD}=0.74$; range $1-5)$. Some variables (especially Time management) also loaded quite strongly other factors than their own factors. Still, every variable's highest loading was on its own factor.

University students' self-regulation, task-avoidance and time management capabilities - a person-oriented approach

The aim of the cluster analysis with SRP, SRC, LR, TA and TIM composite variables was to provide a person-oriented perspective on students' selfregulation. Cluster-analysis is a customary method for a person-oriented approach. The intention was to find distinct groups of students with differing 
self-regulation profiles. More particularly, the aim was to measure what kinds of self-regulatory profiles exist, when the various dimensions measured in this study as perspectives to self-regulation (i.e. SRP, SRC, LR, TA and TIM) were considered. For the cluster analysis, listwise omission was selected to exclude the results where single data was missing. After several analysis and based on theoretical considerations and earlier empirical evidence, a meaningful interpretation with a three-cluster solution was selected. The cluster analysis results are presented in Table 2.

Table 2: Cluster analysis with listwise omission (10 iterations)

\begin{tabular}{|c|c|c|c|c|c|c|}
\hline & $\begin{array}{l}\text { Cluster } 1 \\
\text { Students } \\
\text { with low } \\
\quad \text { self- } \\
\text { regulation } \\
(N=78) \\
\end{array}$ & $\begin{array}{c}\text { Cluster } 2 \\
\text { Students } \\
\text { with high } \\
\text { self- } \\
\text { regulation } \\
(N=74)\end{array}$ & $\begin{array}{c}\text { Cluster } 3 \\
\text { Students } \\
\text { with low } \\
\text { self- } \\
\text { regulation } \\
\text { and high TA } \\
(N=77) \\
\end{array}$ & $\begin{array}{l}\text { All data } \\
(N=230)\end{array}$ & $\mathbf{F}$ & $\begin{array}{c}\text { ETA } \\
\text { Square }\end{array}$ \\
\hline & $M(S D)$ & $M(S D)$ & $M(S D)$ & $M(S D)$ & & \\
\hline SRP & $2.38(.57)_{a}$ & $3.42(.58)_{b}$ & $2.64(.65)_{c}$ & $2.81(.75)$ & 60.90 & 0.35 \\
\hline SRC & $2.56(.58)_{\mathrm{a}}$ & $3.52(.64)_{\mathrm{ab}}$ & $2.76(.63)_{b}$ & $2.94(.74)$ & 51.26 & 0.31 \\
\hline LR & $1.99(.54)_{\mathrm{a}}$ & $2.16(.68)_{\mathrm{a}}$ & $2.80(.58)_{b}$ & $2.32(.70)$ & 38.80 & 0.26 \\
\hline $\mathrm{TA}$ & $2.89(.71)_{\mathrm{a}}$ & $2.24(.71)_{b}$ & $4.35(.71)_{\mathrm{c}}$ & $3.17(1.13)$ & 177.34 & 0.61 \\
\hline TIM & $3.97(.59)_{\mathrm{a}}$ & $4.63(.71)_{b}$ & $2.98(.71)_{\mathrm{c}}$ & $3.86(.95)$ & 116.98 & 0.51 \\
\hline
\end{tabular}

Note. SRP Self-regulated learning process and outcome, SRC Self-regulated learning contents, LR Lack of regulation, TA Task avoidance, TIM Time management, $M$ mean, $S D$ Standard deviation. Means with significant differences are identified with different superscripts (Tuckey $\mathrm{p}<.05$ ).

The first cluster comprised 78 participants (34\%). This group scored relatively low on all items except on task avoidance and time management on which they were in the middle, and we labelled it as students with low self-regulation. The second cluster had 74 participants (32\%), and these students scored high on selfregulation of process and content as well as time management, but low on task avoidance and lack of regulation. This cluster was labelled as students with high self-regulation. The third cluster consisted of 77 participants (34\%). These students scored relatively low on self-regulation on processes and contents, and relatively low on time management, but considerably high on task avoidance and lack of regulation compared to other groups. We thus labelled this cluster as students with low self-regulation and high task avoidance. As was expected with the k-means cluster analysis, the ANOVA table showed statistically significant differences between the clusters in terms of the dependent variables (i.e. SRP. SRC, LR, TA, TIM). In interpreting the means in Table 2, it should be noticed that TA and TIM scales are from 1 to 6 , whereas the rest are from 1 to 5 .

The main difference between the two clusters of low self-regulation (clusters 1 and 3) was that cluster 3 included significantly higher task-avoidance. Tukey's post hoc tests were conducted to point out the significant differences between self-regulation sub-scales and clusters. Thus, there were statistically significant differences $(p<.05)$ on every self-regulation subscale between clusters except in 
SRC between cluster 1 and cluster 3 and in LR between cluster 1 and cluster 2, where there were no statistically significant differences.

\section{Students' self-regulation profiles and learning outcomes}

We compared the cluster groups to the level of learning achievement presented by the course grade. Learning achievements followed general Finnish higher education grading schema (1-5). The grades were not quite distributed equally, and therefore the grades were regrouped as follows: grades 1 and 2 formed the low learning achievement group, grades 3 and 4 formed the intermediate learning achievement group and grade 5 formed the high learning achievement group. Group suppression was made to get more than 5 counts per group for proper analysis (Table 3). Also, suppression made interpretation more appropriate. There seems to be a significant association between clusters and learning achievements $\left(\chi^{2}(4)=13.37, \mathrm{p}<.05\right)$. To further understand the differences, a One-way ANOVA with post-hoc tests were conducted.

In comparing the clusters and learning achievement means by One-way ANOVA, there were statistically significant differences between groups. Tukey's Post hoc test was conducted, and one statistically significant difference was found. It was between students with Cluster 2 (high self-regulation) and Cluster 3 (students with low self-regulation and high TA) $(\mathrm{F}(2.226)=4.696, \mathrm{p}=.10)$. The post-hoc test revealed that students with high self-regulation achieved better compared to students with low self-regulation who reported high task avoidance $(p=.009)$. There were no statistically significant differences between other groups. Between cluster 2 and 3, the effect size was calculated by Cohen's d (Lenhard \& Lenhard, 2016) and it was 0.5, which has been interpreted as an intermediate effect (Cohen, 1988).

Table 3: Learning achievements counts $(\mathrm{N})$ and clusters

\begin{tabular}{|c|c|c|c|c|}
\hline & $\begin{array}{l}\text { Cluster } 1 \\
\text { Students } \\
\text { with low } \\
\text { self- } \\
\text { regulation } \\
(N=78)\end{array}$ & $\begin{array}{c}\text { Cluster } 2 \\
\text { Students } \\
\text { with high } \\
\text { self- } \\
\text { regulation } \\
(N=74)\end{array}$ & $\begin{array}{c}\text { Cluster } 3 \\
\text { Students with } \\
\text { low self- } \\
\text { regulation } \\
\text { and high TA } \\
(N=77)\end{array}$ & $\begin{array}{c}\text { Total } \\
(N=229)\end{array}$ \\
\hline $\begin{array}{l}\text { Learning } \\
\text { achievement - } \\
\text { Cluster } \\
\text { subscale: }\end{array}$ & $\begin{array}{c}n \\
\text { (row \%) }\end{array}$ & $\begin{array}{c}n \\
\text { (row \%) }\end{array}$ & $\begin{array}{c}n \\
\text { (row \%) }\end{array}$ & $\begin{array}{c}n \\
\text { (total \%) }\end{array}$ \\
\hline $\begin{array}{l}\text { Low learning } \\
\text { achievement }\end{array}$ & $\begin{array}{c}15 \\
(40 \%)\end{array}$ & $\begin{array}{c}9 \\
(24 \%)\end{array}$ & $\begin{array}{c}14 \\
(36 \%)\end{array}$ & $\begin{array}{c}38 \\
(100 \%)\end{array}$ \\
\hline $\begin{array}{l}\text { Intermediate } \\
\text { learning } \\
\text { achievement }\end{array}$ & $\begin{array}{c}35 \\
(33 \%)\end{array}$ & $\begin{array}{c}27 \\
(25 \%)\end{array}$ & $\begin{array}{c}45 \\
(42 \%)\end{array}$ & $\begin{array}{c}107 \\
(100 \%)\end{array}$ \\
\hline $\begin{array}{l}\text { High learning } \\
\text { achievement }\end{array}$ & $\begin{array}{c}28 \\
(33 \%)\end{array}$ & $\begin{array}{c}38 \\
(45 \%)\end{array}$ & $\begin{array}{c}18 \\
(21 \%)\end{array}$ & $\begin{array}{c}84 \\
(100 \%)\end{array}$ \\
\hline
\end{tabular}

Note. Cluster counts and percentages compared to learning achievements. The total of every learning achievement category is $100 \%$. 


\section{Discussion}

The purpose of this study was to investigate university students' self-regulation dimensions using a specific questionnaire, for which key composite variable from various studies were used. The perspectives included in the measurements were designed with regard to specific contextual perspectives and requirements on students' learning related to flipped classroom. It was not enough to consider the regulation of contents and processes and lack of regulation, but also students' skills in time management and level of task avoidance were considered important, as students in FC models usually need to plan when and how they use time for preparing for the FC classes in relation to other study requirements. The focus was especially to understand what kind of self-regulation profiles students had in these investigated courses, which were designed based on the flipped classroom approach. Secondly, the aim was to study how the found selfregulation profiles were related to students' learning achievement in terms of the course grade on the flipped classroom course.

First, the questionnaire's internal consistency was tested. EFA showed that the self-regulation subscales (i.e. SRP, SRC, LR, TA and TIM) had strong connections to their own individual dimensions. Still, some of the subscales seemed to overlap with each other (for example TIM), because self-regulation can be seen as a multidimensional phenomenon in which different subscales are related to each other. The reason for that might be that time management is a very dominant aspect of self-regulation as students control it every day. It may also be so that, while students are regulating their learning either in terms of the learning process or the content, they are, at the same time, also managing their time use. Based on the results, the used student self-regulation indicator works well by measuring student self-regulation, task-avoidance and time management.

Next, we used K-means cluster analysis to measure what kind of self-regulation profiles were identified in the sample. Three different profiles were found and named: students with low self-regulation, students with high self-regulation and students with low self-regulation and high task-avoidance. The cluster analysis showed that a student's skills to regulate their learning in terms of the learning process and outcome (SRP) and skills to regulate their learning in terms of the content to be learned (SRC) resonate with each other and are on the same level depending on how high or low the student's self-regulation is. In other words, students that had high self-regulatory skills preferred to use more content outside of the syllabus than students with low self-regulation. Also, the same students did not report lack of regulation or task-avoidance in their studies, which seems reasonable. Instead, students with low self-regulation seemed to have lack of regulation and task-avoidance at some level. However, the amount of lack of regulation and task-avoidance varied a lot between low self-regulated students: students with low self-regulation in cluster 1 did not report having experienced high task-avoidance in their studies, unlike the other low selfregulation group (cluster 3 ). It is noteworthy that low self-regulation is not selfevidently related to high task avoidance in university studies. These results differ in some parts from previous studies, where low self-regulatory skills 
predicted task-avoidance and low learning achievements (see. Nurmi et al., 2003). Finally, active self-regulation is related to more functional time management in university studies, where task-avoidance is related to a more non-functional time management. Therefore, we recommend that students with low self-regulatory skills should be supported by teachers and peers to get selfregulation on at least an intermediate level, for example, by giving constructive feedback (cf. Grow, 1991).

In this study, high self-regulation was related to high learning achievement: highly self-regulating students reported high time management, low lack of regulation and low task-avoidance. Results are similar to previous studies, where high self-regulatory skill students were able to perform better in terms of learning achievements (Beishuizen \& Stoutjesdijk, 1999; Lonka \& Ahola, 1995) and high achievers managed to use their time more properly (Zimmerman \& Martinez-Pons, 1986). However, the results showed that the relation was not so simple, as there was no significant difference in achievement between students of high self-regulated learning skills and students with low self-regulated learning skills, but low self-regulation with task-avoidance seems to lead to problems with achievement in the FC approach. Thus, the only statistically significant difference was between students with high self-regulation of learning and students with low self-regulation of learning and high task-avoidance. Because there was no significant difference between the high self-regulation group and the other passive group, we can figure out that high task-avoidance is a key ingredient in low learning achievements in a Flipped Classroom learning environment. This finding requires further investigation and thought of how to tackle that in the FC pedagogic approach. Through which means, teachers could help students to handle task avoidant tendencies. This is an important issue in FC, as it usually is designed so that it relies on students to take care of and complete the pre-assignments before they come to the face-to-face sessions. It they fail in that, they are also more unlikely to be able to utilize the face-to-face sessions efficiently.

In the lowest-achieving cluster, time management skills were also somewhat lower, in addition to the higher level of task avoidance. In comparison to Pintrich's study (2005), in which self-learners' and high-achievers' time use seemed to be beneficial because of high self-regulation, here the low selfregulation profile was not as unequivocal as it seemed to divide students into two separate clusters, where regulation of the process and content seemed to give a different representation than task avoidance of time management. It may also be so that these challenges of task avoidance and time management emerge together, so that students have difficulties in planning their time use and approximating the time required for them to complete the pre-assignments, which may result in task avoidance behavior. Nevertheless, they might think that they try to reflect on their own learning in terms of the process and outcomes and study deeper the contents while they are doing the learning work, but they have difficulties in getting started. The causal relationships were not investigated here; it remains as a challenge for further research. However, in terms of understanding varying achievements on courses designed according to 
the FC approach, students' challenges in terms of Zimmerman's (2005) forethought phase seem to differentiate between student groups. Thus, if they assume that they will face trouble or challenging tasks, they will find something else to do and will perhaps not study any more. However, they are capable of monitoring their learning during the performance phase (i.e. they try to test their progress by describing the content of paragraphs in their own words, and if they do not understand a study text well, they try to find other literature about the subject concerned) when they have actually started their studying and the contents are not too difficult.

\section{Limitations and future research}

In this study, we used a convenience sample because the response rate among the participants on some of the flipped classroom courses stayed on such a low level that we thought that the received responses might not represent well the perspectives in general among all participants. In further studies, it is recommended to use stronger sampling methods to verify the result of the study.

Moreover, the sample was collected with only those who participated in flipped classroom courses. In future studies it would be meaningful to use a comparison sample from other learning environments. This could give more insights on whether task-avoidance is also common with regular university studies or whether it is only a flipped classroom phenomenon.

In future studies, it could also be interesting to create a regression analysis model to see if self-regulation subscales would predict students' learning achievements. The findings could support course planning as self-regulation subscales' effectiveness would be better known to the student and the teacher.

In this study, we focused on students' self-regulation in relation to learning achievement. Future research could focus on several self-regulation cycles by measuring how self-regulation develops while studying in university and how learning achievement is related to the student's self-regulation. In that way it could be possible to estimate the direction of students' long-term self-regulation and use this information to perhaps provide support for students who are struggling with such challenges in these courses or learning environments designed based on the FC approach. Further research could also benefit from a quasi-experimental design, in which the relations with the low self-regulation skills and task avoidance could be investigated to understand whether this task avoidance challenge is more typical for students studying according to a flipped classroom design.

In future studies external regulation as well as shared regulation could be added to the scales as a subscale of self-regulation. A lot of university courses demand teamwork, where as an individual it can be harder to self-regulate towards one's own goal. 


\section{Acknowledgements}

This study was partially supported by funding from the Finnish Ministry of Education's DigiPeda Flipped learning project [Grant no. OKM/199/523/2016] and TyöPeda project [Grant no. OKM/280/523/2017]. We would like to thank Prof. Jan D. Vermunt for his consultation in the back-translation process of the items of his ILS measurement tool.

\section{References}

Abeysekera, L., \& Dawson, P. (2015). Motivation and cognitive load in the flipped classroom: definition, rationale and a call for research. Higher Education Research $\mathcal{E}$ Development, 34(1), 1-14, doi:10.1080/07294360.2014.934336.

Baeten, M., Kyndt, E., Struyven, K., \& Dochy, F. (2010). Using student-centred learning environments to stimulate deep approaches to learning: Factors encouraging or discouraging their effectiveness. Educational Research Review, 5(3), 243-260. doi:10.1016/j.edurev.2010.06.001

Beishuizen, J., \& Stoutjesdijk, T. (1999). Study strategies in a computer assisted study environment. Learning and instruction, 9(3), 281-301. doi:10.1016/S09594752(98)00027-9

Bergmann, J., \& Sams, A. (2015). Flipped learning for science instruction. The Flipped Learning Series. Retrieved from https://ebookcentral.proquest.com

Berliner, C. \& Biddle, B. (1997). The manufactured crisis. New York: Longman.

Boekarts, M., \& Niemivirta, M. (2000). Self-regulated learning: Finding balance between learning goals and ego-protective goals. In M. Boekarts, P. Pintrich, \& M.

Zeidner (Eds.), Handbook of Self-Regulation (pp. 417-450). San Diego, CA:Academic Press.

Busato, V., Prins, J., Elshout, J., \& Hamaker, C. (1998). Learning styles: A cross-sectional and longitudinal study in higher education. Educational Psychology, 68, 427-441. doi:10.1111/j.2044-8279.1998.tb01302.x

Carver, C., \& Scheier, M. (2005). On the structure of behavioral self-regulation. In M. Boekarts, P. Pintrich, \& M. Zeidner (Eds.) Handbook of Self-Regulation (pp. 41-84). Burlington, MA: Academic Press.

Cohen, J. (1988). Statistical power analysis for the behavioral sciences (2. Auflage). Hillsdale, NJ: Erlbaum.

Entwistle, N. (2003, August). University Teaching-learning Environments and their influences on student learning: An introduction to the ETL project. Paper presented at EARLI Conference, Padova, Italy.

Entwistle, N., \& Peterson, E. (2004). Conceptions of learning and knowledge in higher education: Relationships with study behavior and influences of learning environments. International Journal of Education Research, 41(6), 407-428. doi:10.1016/j.ijer.2005.08.009

Entwistle, N., \& Tait, H. (1990). Approaches to learning, evaluations of teaching, and preferences for contrasting academic environments. Higher Education, 19(2), 169194. doi:10.1007/BF00137106

Eronen, S., Nurmi, J-E., \& Salmela-Aro, K. (1998). Optimistic, defensive-pessimistic, impulsive and self-handicapping strategies in university environments. Learning and Instruction, 8, 159-177. doi:10.1016/S0959-4752(97)00015-7

Field, A. (2018). Discovering statistics using IBM SPSS statistics. London: SAGE Publications Ltd. 
Gijbels, D., Donche, V., Richardson, J. T. E., \& Vermunt, J. D. (Eds.). (2014). Learning patterns in Higher Education. Dimensions and research perspectives. London: Routledge.

Grow, G. (1991). Teaching learners to be self-directed. Adult education quarterly, 41(3), 125-149. doi:10.1177/0001848191041003001

Han, J., \& Kamber, M. (2001). Data Mining: Concepts and Techniques. San Francisco: Morgan Kaufmann.

Hao, Y. (2016). Exploring undergraduates perspectives and flipped learning readiness in their flipped classrooms. Computers in Human Behavior, 59, 82-92. doi:10.1016/j.chb.2016.01.032

Heikkilä, A., \& Lonka, K. (2006). Studying in higher education: students' approaches to learning, self-regulation, and cognitive strategies. Studies in Higher Education, 31, 99-117. doi:10.1080/03075070500392433

Heikkilä, T. (2010). Tilastollinen tutkimus [Statistical Research]. Helsinki, Finland: Edita.

Heikkilä, A., Lonka, K., Nieminen, J., \& Niemivirta, M. (2012). Relations between teacher students approaches to learning, cognitive and attributional strategies, wellbeing, and study success. Higher Education, 64, 455-471. doi:10.1007/s10734-0129504-9

Heikkilä, A., Niemivirta, M., Nieminen, J., \& Lonka, K. (2011). Interrelations among University students' Approaches to learning, Regulation of Learning, and Cognitive and Attributional Strategies: A Person Oriented Approach. Higher Education, 61(5), 513-529. doi:10.1007/s10734-010-9346-2

Hirsto, L. (2012). Certainty of career choice at the beginning of university studies general strategies and attributions in achievement situations, and career motives. Studies for the Learning Society, 2(2-3), 35-45. doi:10.2478/v10240-012$0005-2$

Karagiannopoulou, E., \& Milienos, F. (2015). Testing two path models to explore relationships between students' experiences of the teaching-learning environment, approaches to learning and academic achievement. Educational Psychology, 35(1), 26-52. doi 10.1080/01443410.2014.89580

Lenhard, W., \& Lenhard, A. (2016). Calculation of Effect Sizes. Retrieved from https://www.psychometrica.de/effect_size.html. Dettelbach, Germany: Psychometrica. doi:1 10.13140/RG.2.2.17823.92329

Lonka, K., \& Ahola, K. (1995). Activating instruction - How to foster study and thinking skills in higher education. European Journal of Psychology of Education, 10(4), 351368. doi:10.1007/BF03172926

Lonka, K., Sharafi, P., Karlgren, K., Masiello, I., Nieminen, J., Birgegård, G., \& Josephson, A. (2008). MED NORD-A tool for measuring medical student's well-being and study orientations. Medical Teacher, 30(1), 72-79. doi:10.1080/01421590701769555

MacQueen, J. (1967). Some methods for classification and analysis of multivariate observations. In L. M. Le Cam \& J. Neyman (Eds.), Proceedings of the fifth Berkeley symposium on mathematical statistics and probability, Vol 1. Statistics (pp. 281-297). Retrieved from https://projecteuclid.org/euclid.bsmsp/1200512974.

Mazur, A. D, Brown, B., \& Jacobsen, M. (2015). Learning designs using flipped classroom instruction. Canadian Journal of Learning and Technology, 42(2), 1-26.

Metsämuuronen, J. (2011). Tutkimuksen tekemisen perusteet ihmistieteissä [Conducting research in humanities]. Vaajakoski, Finland: Gummerus Kirjapaino Oy.

Nunnally, J. (1978). Psychometric theory (2nd ed.). New York, NY: McGraw-Hill.

Nurmi, J-E., Aunola, K., Salmela-Aro, K., \& Lindroos, M. (2003). The role of success expectation and task-avoidance in academic performance and satisfaction: Three 
studies on antecedents, consequences and correlates. Contemporary Educational Psychology, 28(1), 59-90. doi:10.1016/S0361-476X(02)00014-0

Nurmi, J-E., Salmela-Aro, K., \& Haavisto, T. (1995). The strategy and attribution questionnaire: Psychometric properties. European Journal of Psychological Assessment, 11(2), 108-121. doi:10.1027/1015-5759.11.2.108

Panadero, E. (2017). A Review of self-regulated learning: Six models and four directions for research. Frontiers in Psychology, 422(8), 1-28. doi:10.3389/fpsyg.2017.00422

Parpala, A., Lindblom-Ylänne, S., Komulainen, E., Litmanen, T., \& Hirsto, L. (2010). Students' approaches to learning and their experiences of the teaching-learning environment in different disciplines. British Journal of Educational Psychology, 80, 269-282. doi:10.1348/000709909X476946

Pintrich, P., \& De Groot, E. (1990). Motivational and Self-Regulated Learning Components of Classroom Academic Performance. Journal of Educational Psychology, 82(1), 33-40. doi:10.1037/0022-0663.82.1.33

Pintrich, P. (1991). A manual for the Use of the Motivated Strategies for Learning questionnaire (MSLQ). Retrieved from https://eric.ed.gov/?q= ED338122

Pintrich, P. (2004). A conceptual framework for assessing motivation and self-regulated learning in college students. Educational Research Review, 16(4), 385-407. doi:10.1007/s10648-004-0006-x

Pintrich, P. (2005). The role of a goal orientation in self-regulated learning. In M. Boekarts, P. Pintrich, \& M. Zeidner (Eds.), Handbook of Self-Regulation (pp. 451502). Burlington, MA: Academic Press.

Toivola, M. (2016). Flipped learning - Why teachers flip and what are their worries? Experiences of Teaching with Mathematics, Sciences and Technology, 2(1), 237-250.

Toivola, M., \& Silfverberg, H. (2015). Flipped learning -approach in mathematics teaching - a theoretical point of view. In P. Hästö \& H. Silfverberg (Eds.), Proceedings of the annual symposium of Finnish mathematics and science education research association 2014 (pp. 93-102). Retrieved from: http://www.protsv.fi/mlseura/julkaisut/malu_2014FINAL.pdf.

Schunk, D. (1994). Self-regulation of self-efficacy and attributions in academic settings. In D. Schunk \& B. Zimmerman (Eds.), Self-regulation of learning and performance: Issues and educational applications (pp. 75-99). Hillsdale, NJ: Erlbaum.

Schunk, D. (2005). Self-Regulated Learning: The Educational Legacy of Paul R. Pintrich. Educational psychologist, 40(2), 85-94. doi:10.1207/s15326985ep4002_3

Schunk, D., \& Ertmer, P. (2005). Self-regulation and academic learning: self-efficacy enhancing interventions. In M. Boekarts, P. Pintrich, \& M. Zeidner (Eds.), Handbook of Self-Regulation (pp. 631-649). Burlington, MA: Academic Press.

Schunk, D., \& Zimmerman, B. (1997). Social origins of self-regulatory competence, Educational Psychologist, 32(4), 195-208. doi:10.1207/s15326985ep3204_1

Sointu, E., Valtonen, T., Cutucache, C., Kukkonen, J., Lambert, C. and Mäkitalo-Siegl, K. (2017). Differences in preservice teachers' readiness to use ICT in education and development of TPACK. In P. Resta \& S. Smith (Eds.), Proceedings of Society for Information Technology \& Teacher Education International Conference (pp. 24622469). Austin, TX, United States: Association for the Advancement of Computing in Education (AACE).

Tait, H., \& Entwistle, N. (1996). Identifying students at risk through ineffective study strategies. Higher Education, 31, 97-116. doi:10.1007/BF00129109

Talbert, R. (2017). Flipped learning - A guide for higher education faculty. Sterling, VA: Stylus Publishing.

Valli, R. (Ed.) (2018). Ikkunoita tutkimusmetodeihin 2: Näkökulmia aloittelevalle tutkijalle tutkimuksen teoreettisiin lähtökohtiin ja analyysimenetelmiin (5. uud. painos) 
[Research methods 2: Perspectives for theoretical foundations and analysis methods]. Jyväskylä, Finland: PS-Kustannus.

Vermunt, J. D. (1994) Inventory of learning styles (ILS). Tilburg, The Netherlands: Tilburg University, Department of Educational Psychology.

Vermunt, J. D. (1996). Metacognitive cognitive and affective aspects of learning styles and strategies: A phenomenographic analysis. Higher Education, 31(1), 25-50. doi:10.1007/BF00129106

Vermunt, J. D., \& Verloop, N. (2000). Dissonance in students regulation of learning processes. European journal of psychology of education, XV, 75-87. doi:10.1007/BF03173168

Vermunt, J. D., \& Vermetten, Y. (2004). Patterns in Student Learning: Relationships Between Learning Strategies, Conceptions of Learning, and Learning Orientations. Educational Psychology Review, 16(4), 359-384. doi:10.1007/s10648004-0005-y

Voogt, J., Erstad, O., Dede, C., \& Mishra, P. (2013). Challenges to learning and schooling in the digital networked world of the 21st century. Journal of computer assisted learning, 29(5), 403-413. doi:10.1111/jcal.12029

Winter, J. (2018). Performance and Motivation in a Middle School Flipped Learning Course. TechTrends, 62(2), 176-183. doi:10.1007/s11528-017-0228-7

Zimmerman, B. (2005). Attaining self-regulation: a social cognitive perspective. In M. Boekarts, P. Pintrich, \& M. Zeidner (Eds.), Handbook of Self-Regulation (pp.13-39). Burlington, MA Academic Press.

Zimmerman, B., \& Martinez-Pons, M. (1986). Development of a Structured Interview for Assessing Student Use of Self-Regulated Learning Strategies. American Educational Research Journal, 23, 614-628. doi:10.3102/00028312023004614

\section{Biographies}

\section{Lauri Hyppönen}

M. Ed. Lauri Hyppönen is a qualified practicing teacher, who conducted a master's thesis under the supervision of Laura Hirsto and Erkko Sointu. This article is based on Lauri Hyppönen's master's thesis work.

\section{Laura Hirsto}

Laura Hirsto (PhD, Educational psychology) is a research director and had been appointed to a professorship in the School of Applied Educational Science and Teacher Education at the UEF, and she is a senior lecturer in university pedagogy at the Higher Education Development Center at the University of Helsinki. Her research interests lie in the studying, learning and motivational processes of higher education students, teacher training, and the research-based development of teaching and learning environments (including FC/L approaches) in various contexts. She is also a trained teacher with experience in both comprehensive and higher education.

\section{Erkko Sointu}

Erkko Sointu (PhD, Education) is a tenure-track assistant professor of learning and novel teaching method development in the School of Educational Sciences and Psychology at the UEF. His research interests lie in the utilization and 
students' perceptions of flipped classroom/learning (FC/L), technology in education, and strength-based approaches in basic education. He has been responsible for large-scale training in FC/ $\mathrm{L}$ for higher education teachers at UEF and also at other universities in Finland and internationally. He is also a trained teacher with experience in both comprehensive and higher education. 